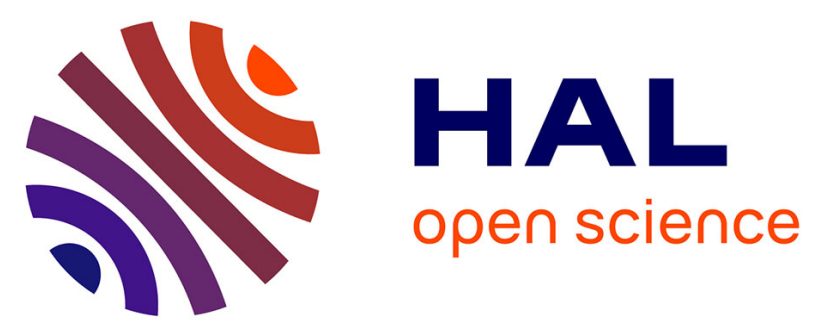

\title{
In-situ biogas upgrading by bio-methanation with an innovative membrane bioreactor combining sludge filtration and $\mathrm{H} 2$ injection
}

Laure Deschamps, Nabila Imatoukene, Julien Lemaire, Mahamadou

Mounkaila, Rayen Filali, Michel Lopez, Marc-André Theoleyre

\section{To cite this version:}

Laure Deschamps, Nabila Imatoukene, Julien Lemaire, Mahamadou Mounkaila, Rayen Filali, et al.. In-situ biogas upgrading by bio-methanation with an innovative membrane bioreactor combining sludge filtration and H2 injection. Bioresource Technology, 2021, 337, pp.125444. 10.1016/j.biortech.2021.125444 . hal-03272414

\author{
HAL Id: hal-03272414 \\ https://hal.science/hal-03272414
}

Submitted on 28 Jun 2021

HAL is a multi-disciplinary open access archive for the deposit and dissemination of scientific research documents, whether they are published or not. The documents may come from teaching and research institutions in France or abroad, or from public or private research centers.
L'archive ouverte pluridisciplinaire HAL, est destinée au dépôt et à la diffusion de documents scientifiques de niveau recherche, publiés ou non, émanant des établissements d'enseignement et de recherche français ou étrangers, des laboratoires publics ou privés. 


\section{Title}

In-situ biogas upgrading by bio-methanation with an innovative membrane bioreactor combining sludge filtration and $\mathrm{H}_{2}$ injection

\section{Authors}

Laure Deschamps $^{1 *}$, Nabila Imatoukene ${ }^{1}$, Julien Lemaire ${ }^{2}$, Mahamadou Mounkaila $^{2}$, Rayen Filali ${ }^{2}$, Michel Lopez ${ }^{1}$, Marc-André Theoleyre ${ }^{3}$

*Corresponding author: laure.deschamps@agroparistech.fr

\section{Affiliations}

${ }^{1}$ URD Agro-Biotechnologies Industrielles (ABI), CEBB, AgroParisTech, 51110

Pomacle, France

${ }^{2}$ Université Paris-Saclay, CentraleSupélec, Laboratoire de Génie des Procédés et Matériaux, SFR Condorcet FR CNRS 3417, Centre Européen de Biotechnologie et de Bioéconomie (CEBB), 3 rue des Rouges Terres, 51110 Pomacle, France

${ }^{3}$ TMA Process, 51100 Reims, France 


\begin{abstract}
A bioreactor using membrane technologies was used to demonstrate the feasibility of in-situ bio-methanation coupled to industrial wastewater treatment for biogas upgrading. High biogas productivity $\left(1.7 \mathrm{Nm}^{3}\right.$ Biogas $/ \mathrm{m}^{3}$ Bioreactor/day) with high $\mathrm{CH}_{4}$ content $(97.9 \%)$ was reached. In-situ bio-methanation did not affect the COD removal efficiency of anerobic digestion (>94\%). Process resilience has been tested for both substrate overload and $\mathrm{H}_{2}$ intermittence injection. Recovery of high $\mathrm{CH}_{4}$ content after 7 days without $\mathrm{H}_{2}$ injection occurred within few hours. Influence of microbial community has been studied showing that both hydrogenotrophic and homoacetogenic-acetoclastic pathways were involved.
\end{abstract}

\title{
Keywords
}

In-situ bio-methanation

Membrane bioreactor

Biogas up-grading

Power-to-Gas 


\section{Introduction}

Anaerobic digestion has the potential to become net producers of renewable energy. However, it leads to biogas production containing $\mathrm{CO}_{2}$ which must be eliminated prior to injection into the gas-grid. Researches on new upgrading process is needed while it is an expensive step of anaerobic digestion plant (Muñoz et al., 2015). Biological conversion of $\mathrm{CO}_{2}$ and $\mathrm{H}_{2}$ to $\mathrm{CH}_{4}$, called bio-methanation (Braga Nan et al., 2020; Wise et al., 1978), is a promising way to upgrade biogas (Luo and Angelidaki, 2013a). During the first three steps of anaerobic digestion process, bacterial population, transform large organic polymer into acetic acid, $\mathrm{CO}_{2}$ and $\mathrm{H}_{2}$. Finally, two paths of methane production take place during methanogenesis. The major way is methane production from acetic acid conversion by acetoclastic methanogens. The second way corresponds to the bio-methanation reaction performed by hydrogenotrophic methanogens according to the following reaction: $4 \mathrm{H}_{2}+\mathrm{CO}_{2} \rightarrow \mathrm{CH}_{4}+2 \mathrm{H}_{2} \mathrm{O}$. In anaerobic digestion, the bio-methanation reaction is limited by $\mathrm{H}_{2}$ amount leading to high $\mathrm{CO}_{2}$ content in biogas. Bio-methanation can be promoted by injecting $\mathrm{H}_{2}$ directly into anaerobic digestor, this is in-situ bio-methanation (Luo and Angelidaki, 2013b). It is also possible to use another bioreactor fed with $\mathrm{H}_{2}$ and $\mathrm{CO}_{2}$ (Díaz et al., 2015), known as ex-situ bio-methanation. Bio-methanation is considered as a value chain of power-togas technologies when hydrogen is produced by water electrolysis from electricity excess from intermittent renewable energies (Götz et al., 2016).

Ex-situ methanation has the advantages of a greater rate of methane produced: methane purity can exceed $95 \%$ with a biogas flowrate up to $288 \mathrm{~m}^{3} / \mathrm{m}^{3}$ reactor/day (Peillex et al., 1990) against only $0.39 \mathrm{~m}^{3} / \mathrm{m}^{3}$ reactor/day (Luo and Angelidaki, 2013b) in the case of insitu methanation. The lower biogas flowrate observed in in-situ methanation is mainly 
due to the limit of biogas produced and thus $\mathrm{CO}_{2}$ produced from anaerobic digestion itself. Compared to ex-situ configuration, in-situ methanation is cheaper as it does not need an additional reactor by using the anaerobic digestion bioreactor for biogas upgrading. However, its microbial consortium is complex and imbalance can occur. Thus, in-situ bio-methanation can alter the microbial community and affect performances of anaerobic digestion. For instance, increase of $\mathrm{H}_{2}$ partial pressure is known to have negative effect on certain population involved in anaerobic digestion, mainly hydrolytic bacteria (Cazier et al., 2015) and acetogenic bacteria (Fukuzaki et al., 1990), which could lead to anaerobic digestion imbalances such as VFA accumulation. Moreover, in-situ bio-methanation tends to increase $\mathrm{pH}$ of fermentation and can lead to a $\mathrm{pH}$ out of the optimal range of anaerobic digestion consortium (6.5-7.5) (Luo and Angelidaki, 2013a; Wang et al., 2013). Indeed, dissolved $\mathrm{CO}_{2}$ consumption leads to $\mathrm{H}^{+}$ consumption according to the following acid-base equilibrium:

$\mathrm{CO}_{2(\mathrm{~g})}+\mathrm{H}_{2} \mathrm{O}_{(\mathrm{l})} \leftrightarrow \mathrm{H}_{2} \mathrm{CO}_{3}(\mathrm{aq}) \leftrightarrow \mathrm{HCO}_{3}^{-}{ }_{(\mathrm{aq})}+\mathrm{H}^{+}{ }_{(\mathrm{aq})}$

In this study, a membrane for sludge filtration was used in order to keep a high microorganism content in the bioreactor and to prevent previously described imbalances due to $\mathrm{H}_{2}$ addition. Acetoclastic microorganisms have low growth rate and their washout can occur and lead to imbalance and VFA accumulation during in-situ biomethanation. It will also prevent washout of $\mathrm{H}_{2}$ sensitive bacteria in case of $\mathrm{H}_{2}$ partial pressure increase. Moreover, adapted microbial community to $\mathrm{H}_{2}$ addition will be kept and concentrated in the bioreactor which can increase progressively $\mathrm{H}_{2}$ consumption rate. The technology used is called an anaerobic membrane bioreactor.

A major bio-methanation limiting factor is $\mathrm{H}_{2}$ dissolution as the latter is poorly soluble in water but must be dissolved to be metabolized by microorganisms. Moreover, it 
should not exceed the inhibiting partial pressure $\left(10^{-5} \mathrm{~atm}\right.$ for VFA degradation Moletta, 2015) and not be present in the upgraded biogas. Few membrane technologies have been developed to enhance $\mathrm{H}_{2}$ gas-to-liquid transfer. Some studies used biofilms formed on the membrane surface (Luo and Angelidaki, 2013a; Wang et al., 2013) or produced microbubbles with possible biogas recycling (Alfaro et al., 2019; Díaz et al., 2015). However, both technologies have major drawbacks. Biofilm technologies required large surface area due to the progressive gas-to-liquid transfer decrease because of the biofilm (Luo and Angelidaki, 2013a) and microbubbles technologies lead to residual hydrogen in upgraded biogas (Alfaro et al., 2019). In this work, a hydrophobic microporous membrane for hydrogen transfer was investigated. Anaerobic digestion medium recirculated through the tubular membrane and hydrogen was injected in the other side of the membrane. Ojeda et al. (2017) also used an external module for gas injection into an anaerobic bioreactor and showed that this technology was efficient for performing hydrogenotrophic fermentation. Moreover, they showed that gas-to-liquid transfer depended on operating conditions such as gas feed pressure. Membrane surface or pore size are also parameters to be considered.

This study aims at investigating the performance of an innovative anaerobic membrane bioreactor for biogas upgrading with high $\mathrm{CH}_{4}$ productivity by in-situ bio-methanation. It combines different microporous membranes for $\mathrm{H}_{2}$ injection and microorganism retention. Moreover, the effect of organic matter and $\mathrm{H}_{2}$ overloads as well as intermittent $\mathrm{H}_{2}$ injection was studied. The evolution of microbial community was investigated to evaluate the influence of in-situ bio-methanation on anaerobic digestion metabolisms. 
2. Material and methods

\subsection{Membrane bioreactor description}

The membrane bioreactor setup is shown in Fig.1. The bioreactor was connected to two external membranes modules with a liquid recirculation pump. The first membrane, used for sludge filtration, was a tubular ceramic module with 19 channels (Orelis Environnement - KLEANSEPTM BW). Its surface area was $0.25 \mathrm{~m}^{2}$ and pore size 0.1 $\mu \mathrm{m}$. Permeate flowrate was controlled by a peristaltic pump which also controlled feed flowrate by natural level adjustment. The bioreactor was fed continuously with substrate in the reserve kept at $5^{\circ} \mathrm{C}$ to prevent any biodegradation. No sludge was discarded during the experiment except for sampling.

The second membrane used for $\mathrm{H}_{2}$ injection is similar to the first one but has been submitted to a hydrophobic surface treatment (fluorinated silanes coating). This membrane was used to dissolve $\mathrm{H}_{2}$ in the bioreactor medium. $\mathrm{H}_{2}$ was produced continuously by a water electrolysis device (Peak scientific 450cc) and hydrogen flowrate was regulated by a $\mathrm{H}_{2}$ flowmeter (Bronks SLA5850). Bioreactor mixing was ensured by liquid recirculations. Recirculation in the membrane was $700 \mathrm{~L} / \mathrm{h}$. A pH and temperature probe (JUMO 201020) and a sludge sample point were placed in another recirculation loop. The temperature was set at $37{ }^{\circ} \mathrm{C}$ with a water bath and coil in the bioreactor. No $\mathrm{pH}$ adjustment was done in the bioreactor.

\subsection{Sludge inoculum}

The pilot scale anaerobic membrane bioreactor was inoculated with effluent from an anaerobic packed bed bioreactor treating the same wastewater used in this study as described previously (Deschamps et al., 2021). 


\subsection{Wastewater}

The substrate used as nutrient feedstock was a wastewater of an industrial distillery which produces bioethanol from sugar beet and wheat (Cristanol, Bazancourt, France). It was a blend of evaporation condensate and cleaning water of tanks. Suspended solids represented $3 \pm 1 \mathrm{~g} / \mathrm{L}$, total nitrogen $180 \pm 90 \mathrm{mg} / \mathrm{L}$ and sulfate $220 \pm 80 \mathrm{mg} / \mathrm{L}$. A new batch of fresh wastewater was collected every two to three weeks. Initial $\mathrm{pH}$ of the wastewater was $4.5 \pm 0.5$ and was adjusted to $7 \pm 0.2$ while working in anaerobic digestion process only. No $\mathrm{pH}$ adjustment was done when $\mathrm{H}_{2}$ was added. Average total COD concentration of the wastewater was $12 \pm 2 \mathrm{~g}_{\mathrm{COD}} / \mathrm{L}$.

\subsection{Experimental setup}

The bioreactor was running for 5 months in anaerobic digestion process only before starting in-situ bio-methanation experiment.

First, during transition phase between phase 0 and phase 1 , hydrogen flowrate was slowly increased in order to prevent $\mathrm{H}_{2}$ inhibition of microorganisms starting at 0.8 $\mathrm{NL} / \mathrm{h}$. During this transition, $\mathrm{H}_{2}$ flowrate was doubled when less than $1 \%$ of $\mathrm{H}_{2}$ was detected in the biogas until it reached the stoichiometric flowrate (molar ratio of $4 \mathrm{H}_{2} / 1$ $\mathrm{CO}_{2}$ ). Flowrate of $\mathrm{H}_{2}$ was manually controlled according to flowrate of remained $\mathrm{CO}_{2}$ in the biogas. Then, bio-methanation ramp-up was composed of 3 phases. In the first phase, $\mathrm{H}_{2}$ was added stoichiometrically with $\mathrm{CO}_{2}$ produced by anaerobic digestion. Hydraulic retention time (HRT) was fixed at 3.3 days, corresponding to an organic loading rate (OLR) equal to $2.7 \mathrm{~kg} \mathrm{COD} / \mathrm{m}^{3} /$ day. Then, during the second phase, OLR was increased to $3.9 \mathrm{~kg}_{\mathrm{COD}} / \mathrm{m}^{3} /$ day by decreasing HRT to 2.8 days in order to increase process productivity. $\mathrm{H}_{2}$ was increased as well, stoichiometrically to the $\mathrm{CO}_{2}$ produced. 
During the third phase, liquid pressure in the injection membrane was increased in order to enhance $\mathrm{H}_{2}$ gas-to-liquid transfer.

Then, during the fourth phase, high organic content substrate $\left(15 \mathrm{~g}_{\mathrm{COD}} / \mathrm{L}\right)$ and increase of $60 \%$ of OLR within 2 days was used to mimic an overloading situation and evaluate its effect on in-situ bio-methanation. When process performances were recovered, $\mathrm{H}_{2}$ injection was stopped for 7 days in order to evaluate the feasibility of intermittent $\mathrm{H}_{2}$ addition for in-situ bio-methanation (phase 5).

\subsection{Analytical procedure}

During all operations, buffer capacity (TAC) and biogas composition were recorded daily. Volatile fatty acids (VFA) and chemical oxygen demand (COD) were measured 3 times a week.

Online data acquisition was carried out every $10 \mathrm{~min}$ for the weight of produced permeate (with OHAUS balance type DEFENDER 5000), the volume of produced biogas (with drum gas meter RITTER TG 0.5 ) and the $\mathrm{pH}$ value. All these devices were connected to a computer for reading, processing, synchronizing and displaying data in real time. The balance had a RS232 communication port which was connected directly to the computer. The gas meter had a rotary encoder associated with a pulse generator that produced one pulse (TTL signal from 0.7 to $3.7 \mathrm{~V}$ ) for each $0.0025 \mathrm{NL}$ of produced biogas. The $\mathrm{pH}$ probe was connected to the JUMO ecoTRANS $\mathrm{pH}$ transmitter, which had an analog output of 2 to $10 \mathrm{~V}$ depending on the $\mathrm{pH}$ value from 0 to 14 . The analog outputs of the gas meter and the $\mathrm{pH}$ transmitter were connected to inputs of an ad hoc 16-bit analog-to-digital converter (ADC). The ADC was connected to the computer through USB interface. Reading, processing, recording and displaying of all the data was done with the LabVIEW software. A sliding average and a median were carried out 
on the signal from the balance in order to reduce noise. A software was developed to count pulses from the gas meter and convert them into gas volume.

TAC value was measured by $\mathrm{pH}$ titration using $0.1 \mathrm{~N} \mathrm{H}_{2} \mathrm{SO}_{4}$ based on the Nordmann method (Lili et al. 2011). It was determined through titration of $20 \mathrm{~mL}$ of sample up to pH 5. COD analysis was performed using Spectroquant ${ }^{\circledR}$ cell tests (1.14541) with Spectroquant ${ }^{\circledR}$ Multy photometer.

VFA analysis was performed using HPLC (Ultimate 3000 Thermo Fisher) with an Aminex HPX-87H $(7.8 \times 300 \mathrm{~mm}, 9 \mu \mathrm{m})$ column at $50{ }^{\circ} \mathrm{C}$ with $\mathrm{UV}$ detection. The mobile phase was $8 \mathrm{mM} \mathrm{H}_{2} \mathrm{SO}_{4}$ at $0.8 \mathrm{~mL} / \mathrm{min}$, and $20 \mu \mathrm{L}$ of sample was injected for analysis. Acetic, butyric, and propionic acids were quantified.

Biogas analysis was carried out on micro-GC 490 from Agilent Technologies. Biogas sample was introduced through a heated line at $100{ }^{\circ} \mathrm{C}$. Three columns were used: a molecular sieve $5 \AA$ (MS-5A, 10 m) to quantify $\mathrm{H}_{2}$ using Argon as the carrier gas, another molecular sieve $5 \AA$ (MS-5A, 10 m) to separate $\mathrm{O}_{2}, \mathrm{~N}_{2}$ and $\mathrm{CH}_{4}$ and a PoraPLOT U (PPU, $10 \mathrm{~m}$ ) to quantify $\mathrm{CO}_{2}$, both columns used Helium as the carrier gas. Separation was achieved at $100{ }^{\circ} \mathrm{C}, 100{ }^{\circ} \mathrm{C}$ and $60{ }^{\circ} \mathrm{C}$ with a backflush of $26 \mathrm{~s}, 4.7$ $\mathrm{s}$ and $16 \mathrm{~s}$, respectively. Columns pressure was $29 \mathrm{psi}$. The detector was a Thermal Conductivity Detector (TCD). Total run lasted $80 \mathrm{~s}$. Calibration was performed using standard gases (Air Liquide) and diluted using flowmeters from Bronkhorst. Quantification was achieved using peaks area with an external calibration (concentration range from 0.05 to $100 \%$ ).

\subsection{Microbial analysis}

Microbial analysis was performed by qPCR in order to quantify total archaea (ARC) and bacteria (BAC) in the reactor. Quantification was also carried out for the following 
hydrogenotrophic methanogen archaea: Methanococcales (MCC), Methanomicrobiales (MMB), Methanobacteriales (MBT) and, acetoclastic methanogen archaea Methanosaetaceae (Mst) (Garrity et al., 2001). Methanosarcinales (MSL) were quantified as well. Regarding bacterial community, the following phylum were quantified: Sulfate-reducing bacteria (SRB) and Bacteroidetes (BDT).

$50 \mathrm{~mL}$ of sludge samples were collected during each phase and during transition phase and were centrifuged (4000 g, $15 \mathrm{~min})$. DNA was extracted from pellets with PowerSoil® DNA Isolation Kit (MO BIO, Qiagen) according to manufacturer's instructions. Plasmids including the target sequences (pET-15b, GenScript) were used as reference sample excepted for total bacteria where DNA was extracted from pure culture of Bacillus subtilis and then was used as standard. Serial dilutions of reference sample were prepared to establish the qPCR calibration curve.

qPCR was performed by targeting $16 \mathrm{~S}$ rRNA coded by $16 \mathrm{~S}$ rDNA except for SRB which was performed by targeting $D s r B$ gene. Ssoadvanced universal sybr green supermix (Bio-Rad) was used with C1000 touch thermal cycler CFX96 (Bio-Rad). qPCR mix were composed of $10 \mu \mathrm{L}$ of master mix, $1 \mu \mathrm{L}$ of DNA and $2 \mu \mathrm{L}$ of each primer $(2 \mu \mathrm{M})$ for each target, except for BDT where $1 \mu \mathrm{L}$ of primers was used, for a final volume of $20 \mu \mathrm{L}$.

Primer specificity were validated for each target with pure DNA and sample DNA by performing analysis of the amplicon melting curves which showed one peak corresponding to one amplicon. They were established by increasing the temperature from $72{ }^{\circ} \mathrm{C}$ to $95^{\circ} \mathrm{C}$ and by measuring the fluorescence intensity after amplification cycles. 
3. Results and discussion

\subsection{Bioreactor performance}

Performance of anaerobic digestion and bio-methanation are shown in Table 1 for the first three phases. Bioreactor performances of all experiment are shown in Fig. 2. During the phase 0 , when only anaerobic digestion was performed, methane content of 74.7\% was reached which is common for distillery wastewater (Moletta, 2005). Moreover, high digestion performance was observed. A previous study focusing on membrane filtration performance and anerobic digestion was published showing how this technology leads to high OLR, COD removal efficiency and biogas production (Deschamps et al., 2021).

First, $\mathrm{H}_{2}$ flowrate was slowly increased in order to prevent $\mathrm{H}_{2}$ inhibition of microorganisms starting at $0.8 \mathrm{NL} / \mathrm{h}$. During this transition, $\mathrm{H}_{2}$ flow rate was doubled every 4 days on average, when less than $1 \%$ of $\mathrm{H}_{2}$ was detected in the biogas until it reached the stoichiometric flowrate. 20 days after the beginning of $\mathrm{H}_{2}$ addition, $\mathrm{H}_{2}$ was added stoichiometrically to $\mathrm{CO}_{2}$ produced. Then, during the first phase, $98.9 \%$ of $\mathrm{H}_{2}$ added was consumed when HRT was fixed at 3.3 days, corresponding to OLR equal to $2.7 \mathrm{~kg}_{\mathrm{COD}} / \mathrm{m}^{3} /$ day. This led to high $\mathrm{CH}_{4}$ content in the biogas $(97.4 \%)$ which is high enough for biogas gas-grid injection. $\mathrm{pH}$ increased from 7.3, without $\mathrm{H}_{2}$ addition, to 7.6 although feed $\mathrm{pH}$ was decreased to limit this $\mathrm{pH}$ increase by using wastewater without $\mathrm{pH}$ adjustment. Then, during the second phase, OLR was increased to $3.9 \mathrm{~kg}_{\mathrm{COD}} / \mathrm{m}^{3} / \mathrm{day}$ by decreasing HRT to 2.8 days in order to increase the process productivity. $\mathrm{H}_{2}$ consumption yield decreased to $84.3 \%$ which led to a lower $\mathrm{CH}_{4}$ content in the biogas (82.8\%). During the third phase, $\mathrm{H}_{2}$ gas-to-liquid transfer was improved significantly by increasing the pressure of the liquid size of the injection membrane: $\mathrm{H}_{2}$ consumption 
yield was $99.2 \%$ and $\mathrm{CH}_{4}$ biogas content reached $97.9 \%$ with a higher OLR (4.4 $\left.\mathrm{kg}_{\mathrm{COD}} / \mathrm{m}^{3}{ }_{\text {Bioreactor }} / \mathrm{day}\right)$. Thus, higher productivity of biogas was reached: $10.8 \mathrm{NL} / \mathrm{h}$ which correspond to $1.7 \mathrm{Nm}^{3}{ }_{\text {Biogas }} / \mathrm{m}^{3}$ Bioreactor/day. During the first three phases, COD removal efficiency remained high (> 94\%) and VFA remained below quantification $\operatorname{limit}(<0.02 \mathrm{~g} / \mathrm{L})$.

These results confirmed that anaerobic digestion consortium is able to catalyze the methanation reaction. Moreover, the high COD removal efficiency showed that the insitu bio-methanation did not affect the anaerobic digestion process. Despite $\mathrm{pH}$ increase all along the experiment, from 7.6 in phase $1,7.7$ in phase 2 and up to 7.9 in phase 3 , it was still within the optimal range of anaerobic digestion without any $\mathrm{pH}$ control. $\mathrm{pH}$ increase is explained by $\mathrm{CO}_{2}$ consumption which led to displacement of carbonatebicarbonate equilibrium in the liquid phase. Indeed, buffer capacity (TAC) decreased from $1866 \pm 155 \mathrm{mg}_{\mathrm{CaCO} 3} / \mathrm{L}$ before $\mathrm{H}_{2}$ addition to $1122 \pm 74 \mathrm{mg} \mathrm{CaCO}_{3} / \mathrm{L}$ during the first phase. $\mathrm{pH}$ increase up to 8.3 was also observed in other studies without affecting the anaerobic digestion performance (Luo and Angelidaki, 2013b, 2013a). Keeping pH within optimal range for anaerobic digestion was possible in the present study because low pH wastewater was used. Luo and Angelidaki (2013b) also showed that feeding the bioreactor with acidic substrate was a way to keep $\mathrm{pH}$ optimal for anaerobic digestion during in-situ bio-methanation.

During the first phase, high $\mathrm{H}_{2}$ consumption yield and $\mathrm{CH}_{4}$ content were reached showing that the membrane technology used was able to dissolve high amount of hydrogen with very low $\mathrm{H}_{2}$ residual content (1.1\%). However, OLR was relatively low during this phase compared to phase 0 because of low COD content of the wastewater batch used $\left(8.8 \mathrm{~g}_{\mathrm{COD}} / \mathrm{L}\right)$. 
Therefore, OLR was increased during the second phase by using a new wastewater batch with higher COD content (10.8 $\left.\mathrm{g}_{\mathrm{COD}} / \mathrm{L}\right)$, as well as decreasing HRT to 2.8 days. However, increasing both OLR and $\mathrm{H}_{2}$ injection led to a $\mathrm{CH}_{4}$ content decrease (82.8\%) because of lower bio-methanation efficiency which led to high $\mathrm{H}_{2}$ residual content (12.9\%) and $\mathrm{CO}_{2}$ residual content (4.3\%). It could be the results of either non-dissolved $\mathrm{H}_{2}$ or non-consumed $\mathrm{H}_{2}$ by microorganisms. Dissolved but not consumed $\mathrm{H}_{2}$ would lead to $\mathrm{H}_{2}$ concentration increase in the liquid phase. However, dissolved $\mathrm{H}_{2}$ accumulation is known to be toxic for the bacterial community during anaerobic digestion (Cazier et al., 2015; Fukuzaki et al., 1990) and would conduct to a decrease of COD removal efficiency. As COD removal efficiency remained high during the second phase, it is assumed that $\mathrm{H}_{2}$ residual content was mainly due to non-dissolved $\mathrm{H}_{2}$. This demonstrated the need to increase the limit of $\mathrm{H}_{2}$ gas-to-liquid transfer to improve overall process performance. Yasin et al., 2015 suggested that gas-to-liquid transfer could be improved by either increasing injection membrane surface area, liquid flowrate or gas pressure.

$\mathrm{H}_{2}$ pressure in the membrane was adjusted by the gas flowmeter to deliver the desired flowrate. As $\mathrm{H}_{2}$ pressure depends on liquid pressure in the injection membrane, to improve $\mathrm{H}_{2}$ effective dissolution, liquid pressure was increased in the membrane from 0.4 to 0.6 bar $_{\mathrm{g}}$ in the third phase. It led to a higher $\mathrm{H}_{2}$ consumption yield (99.2\%) than second phase despite the higher $\mathrm{H}_{2}$ feed flowrate $(11.6 \mathrm{NL} / \mathrm{h})$ required to meet stoichiometric $\mathrm{CO}_{2}$ demand at higher OLR $\left(4.4 \mathrm{~kg} \mathrm{COD} / \mathrm{m}^{3} /\right.$ day $)$. This result confirmed that liquid pressure is a crucial parameter for effective $\mathrm{H}_{2}$ dissolution. Bioreactor pressure had already been shown to affect $\mathrm{H}_{2}$ gas-to-liquid transfer for bio-methanation by Díaz et al., 2020 who increased methane purity from $69.4 \%$ to $92.9 \%$ by increasing 
bioreactor pressure from 0.2 barg $_{\mathrm{g}}$ to 0.3 bar $_{\mathrm{g}}$. Increasing bioreactor pressure led to a $\mathrm{H}_{2}$ solubility increase according to Henry's law which says that "the amount of a given gas that dissolves in a given type and volume of liquid is directly proportional to the partial pressure of that gas in equilibrium with that liquid":

$$
H_{2} \text { saturation concentration }=H_{2} \text { Henry's constant } \times H_{2} \text { pressure }
$$

Moreover, the flux of $\mathrm{H}_{2}$ transfer from gaseous phase to liquid phase can be calculated according to the following formula (Jensen et al., 2021):

$\mathrm{H}_{2}$ flux $=\mathrm{H}_{2}$ volumetric mass transfer coefficient $\times$

$$
\text { ( } \mathrm{H}_{2} \text { saturation concentration }-\mathrm{H}_{2} \text { concentration in liquid phase) }
$$

This shows the correlation between pressure of $\mathrm{H}_{2}$ and flux of $\mathrm{H}_{2}$. However, pressure can also affect the $\mathrm{H}_{2}$ volumetric mass transfer coefficient, at higher pressure, medium viscosity increased which can cause surface tension decrease, and consequently led to the formation of smaller bubbles, increasing gas-to-liquid transfer inside the bioreactor (Lau et al., 2004).

During the third phase, it was feasible to produce up to $1.7 \mathrm{Nm}^{3}{ }_{\text {Biogas }} / \mathrm{m}^{3}$ Bioreactor $/$ day with a $\mathrm{CH}_{4}$ content up to $97.9 \%$, which corresponds to a higher heating value compatible with gas-grid injection $\left(10.88 \pm 0.05 \mathrm{kWh} / \mathrm{Nm}^{3}\right.$ Biogas $)$. As initial composition of biogas with the treated wastewater is about $75 \%$ of $\mathrm{CH}_{4}$ content and $25 \%$ of $\mathrm{CO}_{2}$ content, it can be assumed that, during the third phase, about $75 \%$ of the $\mathrm{CH}_{4}$ is produced from the wastewater treatment and $25 \%$ of the $\mathrm{CH}_{4}$ is produced from $\mathrm{H}_{2}$ and $\mathrm{CO}_{2}$.

Compared to similar recent studies, such productivity and $\mathrm{CH}_{4}$ content were higher and quite outstanding. Other studies on in-situ bio-methanation used injection membrane module to improve $\mathrm{H}_{2}$ dissolution are presented in Table 2. Díaz et al., 2015 showed that micro-bubbling through porous hollowfiber membranes was a way to reach very 
high $\mathrm{k}_{\mathrm{L}}$ a value for $\mathrm{H}_{2}$ gas-to-liquid transfer (up to $430 \mathrm{~h}^{-1}$ ). However, when used directly in the bioreactor for in-situ bio-methanation, it led to a significant $\mathrm{H}_{2}$ residual content (> 7.2\%) in the produced biogas (Alfaro et al., 2019) despite a lower $\mathrm{H}_{2}$ feed flowrate of $7.8 \mathrm{NL}_{\mathrm{H} 2} / \mathrm{m}^{2}$ membrane $/ \mathrm{h}, 5.9$-times lower than the present study. Biofilm formation by using dense membrane is a way to prevent any $\mathrm{H}_{2}$ residue in the produced biogas (Luo and Angelidaki, 2013a; Wang et al., 2013). However, these technologies required high specific membrane area: $119 \mathrm{~m}^{2} / \mathrm{m}^{3}$ Bioreactor (Luo and Angelidaki, 2013a) and 58 $\mathrm{m}^{2} / \mathrm{m}^{3}$ Bioreactor (Pratofiorito et al., 2021) while only $1.7 \mathrm{~m}^{2} / \mathrm{m}^{3}$ Bioreactor was used in the present study. Moreover, biofilm technology provided lower methane production rate: $1.2 \mathrm{Nm}^{3} / \mathrm{m}^{3}$ Bioreactor/day (Pratofiorito et al., 2021) and $0.9 \mathrm{Nm}^{3} / \mathrm{m}^{3}$ Bioreactor/day (Luo and Angelidaki, 2013a).

The technology developed in this work combined the advantage of lower $\mathrm{H}_{2}$ residue in the produced biogas and lower specific membrane area required. However, high recirculation flowrate was needed in the present study for $\mathrm{H}_{2}$ dissolution which can lead to high operational cost at industrial scale. The results showed that $\mathrm{H}_{2}$ gas-to-liquid transfer can be improved by increasing liquid pressure. Thus, bioreactor pressure could be naturally increased during biogas production which does not require additional energy. Nevertheless, further studies are required to have a better understanding of the influence of recirculation rate and liquid pressure on $\mathrm{H}_{2}$ gas-to-liquid transfer and $\mathrm{H}_{2}$ residual content in the produced biogas.

\subsection{Process resilience}

3.2.1 Phase 4: Overload organic matter and $\mathrm{H}_{2}$ 
At the end of the third phase, a new batch of wastewater with high COD content (15.0 $\mathrm{g}_{\mathrm{COD}} / \mathrm{L}$ ) and an increase of OLR up to $7.3 \mathrm{~kg} \mathrm{COD} / \mathrm{m}^{3}$ Bioreactor $/$ day was used to mimic an overload situation which is a common cause of anaerobic digestor failure. $\mathrm{H}_{2}$ flowrate was fixed at $15 \mathrm{NL} / \mathrm{h}$ in order to be added stoichiometrically with estimated $\mathrm{CO}_{2}$ produced with this new batch and was not changed during this period. The effect of insitu bio-methanation during an overload was studied. Biogas production (including unconsumed $\mathrm{H}_{2}$ ), $\mathrm{pH}$ and VFA concentration measured during this period are shown in Fig. 3.

Acidification started at day 74 leading to a progressive biogas production shortage. $\mathrm{pH}$ decrease was due to VFA accumulation and significant reduction of biogas production was observed. Decrease of biogas production led to excess of $\mathrm{H}_{2}$ added compared to $\mathrm{CO}_{2}$ produced. The turning point where $\mathrm{H}_{2}$ was added in excess can be seen in Fig. 3 at day 77. From this point, $\mathrm{pH}$ stopped to decrease and start to increase which means that $\mathrm{CO}_{2}$ was fully consumed. Indeed, during anaerobic digestion, $\mathrm{pH}$ is stabilized by carbonate-bicarbonate buffer (Murphy and Thanasit Thamsiriroj, 2013). Thus, when $\mathrm{CO}_{2}$ was consumed, $\mathrm{pH}$ increased despite feeding with wastewater at low $\mathrm{pH}$ and VFA accumulation in the bioreactor. This suggests that hydrogenotrophic activity was still high compared to acetogenic activity which confirms that hydrogenotrophic methanogen have higher consumption rate or higher growth rate than acetogenic methanogen in these experimental conditions. Hydrogenotrophic methanogen are known to have higher growth rate than acetoclastic methanogen (Murphy and Thanasit Thamsiriroj, 2013).

Moreover, at the same time, apparent biogas production flowrate stabilized around 10.5 $\mathrm{NL} / \mathrm{h}$ whereas it would have been expected that biogas production kept on decreasing. 
Actually, biogas production decreased but was counterbalanced by the excess of unconsumed $\mathrm{H}_{2}$ in headspace which was recorded with the biogas produced. A plateau was observed because anaerobic digestion of this wastewater usually produces a biogas with $75 \%$ of $\mathrm{CH}_{4}$ and $25 \%$ of $\mathrm{CO}_{2}$. Thus, one volume of biogas which was not produced led to one volume of $\mathrm{H}_{2}$ not consumed, which resulted in an apparent stabilized biogas production.

Biogas production variation occurred when $\mathrm{pH}$ exceeded 8 (day 78) suggesting that microbial community and metabolic pathways changed either because of high $\mathrm{pH}$ or high $\mathrm{H}_{2}$ partial pressure. At this point, VFA content in the bioreactor was $1.41 \mathrm{~g} / \mathrm{L}$ of acetic acid, $0.55 \mathrm{~g} / \mathrm{L}$ of propionic acid and $0.97 \mathrm{~g} / \mathrm{L}$ of butyric acid. Compared to day 75 , acetic acid concentration did not increase while longer chain VFA accumulation was observed, suggesting that acetogenesis was inhibited at this stage due to increase $\mathrm{H}_{2}$ partial pressure or high $\mathrm{pH}$. VFA accumulation had also been observed in other study operating at high $\mathrm{H}_{2}$ partial pressure and had been shown to be dependent on initial microbial community used (Braga Nan et al., 2020). Moreover, propionate biodegradation by acetogenesis bacteria had been shown to be inhibited by high $\mathrm{H}_{2}$ partial pressure (Fukuzaki et al., 1990). High pH had also been shown to have high effect on VFA production during anaerobic fermentation (Horiuchi et al., 2002). At day 78, headspace was composed of $50 \% \mathrm{CH}_{4}$ and $50 \% \mathrm{H}_{2}$ confirming that $\mathrm{CO}_{2}$ was totally consumed.

$\mathrm{H}_{2}$ addition was stopped when $\mathrm{pH}$ reached 9 (day 78), then $\mathrm{pH}$ value dropped below 6.5 in only 2 hours. This quick decrease suggests $\mathrm{CO}_{2}$ production by the bacterial community which was still able to perform first steps of anaerobic digestion despite high $\mathrm{pH} . \mathrm{H}_{2}$ injection was restarted when $\mathrm{pH}$ decreased below 6.5 (day 78) in order to 
prevent any further $\mathrm{pH}$ decrease which would lead to methanogenesis inhibition.

Stopping $\mathrm{H}_{2}$ addition in excess led to consumption of butyric and propionic acids confirming the previous inhibition of bacteria involved in their degradation because of high $\mathrm{H}_{2}$ partial pressure. However, high acetic acid concentration was still observed (> 2 g/L) 5 days after $\mathrm{H}_{2}$ injection restart showing that acetoclastic methanogen community content was not high enough to consume all acetic acid produced by the first step of methanogenesis. Thus, decreasing both OLR and $\mathrm{H}_{2}$ was needed to recover a good productivity.

These results showed that $\mathrm{H}_{2}$ addition has a huge impact on the bioreactor $\mathrm{pH}$ and on metabolic pathways. Thus, $\mathrm{H}_{2}$ flowrate has to be controlled accurately and continuously based on $\mathrm{CO}_{2}$ production and $\mathrm{pH}$ in order to keep the process in optimal condition for anaerobic digestion as well as high biogas $\mathrm{CH}_{4}$ content.

\subsubsection{Phase 5: Intermittent $\mathrm{H}_{2}$ addition}

Feasibility of in-situ bio-methanation is considered as economically and environmentally sustainable if its uses $\mathrm{H}_{2}$ produced from water electrolysis with renewable electricity excess such as intermittent wind or solar energy (Fu et al., 2020). Thus, in the fifth phase, $\mathrm{H}_{2}$ addition was stopped for 7 days then upturned to mimic the effect of intermittent $\mathrm{H}_{2}$ addition due to intermittent electricity production from renewable energy. Results showed a quick effect of $\mathrm{H}_{2}$ addition interruption on methane purity which returned to $75 \%$ with $25 \%$ of $\mathrm{CO}_{2}$ the day after $\mathrm{H}_{2}$ injection was turned off. Interestingly, methane content went back to high content (93\%) with no $\mathrm{H}_{2}$ residue detected in biogas less than $24 \mathrm{~h}$ after $\mathrm{H}_{2}$ addition resumption. Moreover, continuously 
monitored biogas flowrate suggests that $\mathrm{H}_{2}$ was directly consumed, within few hours, after $\mathrm{H}_{2}$ resumption.

These outcomes demonstrate the resilience of the developed in-situ bio-methanation membrane bioreactor. It appears that hydrogenotrophic methanogens activity was not affected by stopping $\mathrm{H}_{2}$ addition for 7 days. One week of total $\mathrm{H}_{2}$ shortage is a much longer period than expected with intermittent renewable energy. Therefore, intermittent $\mathrm{H}_{2}$ addition is biologically feasible without affecting the hydrogenotrophic activity of the flora present in the in-situ bio-methanation bioreactor. Moreover, a quick restart of $\mathrm{H}_{2}$ injection to $100 \%$ of $\mathrm{CO}_{2}$ stoichiometry demand did not affect the COD removal efficiency showing that $\mathrm{H}_{2}$ was directly used by the hydrogenotrophic microorganisms without any accumulation in liquid and gas phases. A slight decrease of COD removal efficiency $(88 \%)$ was observed after $\mathrm{H}_{2}$ stop but came back to high level (>90\%) within 2 days. It can be explained by a volume, representing $4 \%$ of the total bioreactor volume, taken out for analysis reducing the total microbial community in the bioreactor.

\subsection{Microbial community analysis}

MCC were lower than quantification limit in all samples. Mst represented almost $100 \%$ of MSL in all samples, thus, only Mst results are shown. Results of microbial community analysis are shown in Fig. 4.

Both total archaea and bacteria populations increased between the anaerobic digestion initial phase and the transition phase (6 days after with progressive $\mathrm{H}_{2}$ injection). Among archaea phylum, both Mst and MMB population increased. Proportion of Mst was 1.2-fold higher during the transition phase and MMB 2.7-fold higher suggesting that both homoacetogenic-acetoclastic and hydrogenotrophic pathways co-existed. Then, during the first phase, MMB increased 3-fold and Mst decreased and came back 
to its initial proportion. These results suggest that in-situ bio-methanation is feasible with few adaptations of microbial community by first using mainly the homoacetogenic-acetoclastic pathway. Then, hydrogenotrophic MMB growth was stimulated by $\mathrm{H}_{2}$ addition and was faster than $M s t$ growth. Thus, adaptation of microbial community occurred after 3 weeks of $\mathrm{H}_{2}$ injection in the bioreactor and increased the use of hydrogenotrophic pathway.

From the first and second phases, in-situ bio-methanation was limited by low $\mathrm{H}_{2}$ gas-toliquid transfer, then $\mathrm{H}_{2}$ supply was not sufficient to meet the demand due to OLR increase. It resulted in a 2.5-fold decrease of total bacteria despite OLR increase. It suggests that bacteria played an important role on bio-methanation during the first phase and thus that homoacetogenic-acetoclastic pathway was still important for biomethanation.

Moreover, comparison of microbial community between the second and third phases showed that increasing of $\mathrm{H}_{2}$ gas-liquid transfer led to a direct consumption of $\mathrm{H}_{2}$ with only few changes of microbial community (MMB proportion by 1.4-fold increase). Wang et al., 2013 also reported that both ways of methane production co-exist during in-situ biogas upgrading by bio-methanation and that hydrogenotrophic archaea were stimulated by $\mathrm{H}_{2}$ addition.

Analysis of microbial community after an organic matter overload, which resulted in excess of $\mathrm{H}_{2}$, showed a significant increase of bacterial community and MMB proportion (see Fig. 4). Increasing of bacterial community was most probably due to COD overload than indirect $\mathrm{H}_{2}$ excess. Indeed, when an anaerobic digestor is overloaded with organic matter, acidification occur because bacterial community involved in acidogenesis and acetogenesis steps have higher growth rate than 
acetoclastic archaea leading to accumulation of acetic acid in the bioreactor. Moreover, the excess of $\mathrm{H}_{2}$ added led to 6.3-fold increase of MMB proportion while $M s t$ did not increase despite acetic acid accumulation. This result confirmed that hydrogenotrophic archaea have a higher growth rate than acetoclastic archaea in the experimental conditions.

Analysis of SRB shows no significant influence of $\mathrm{H}_{2}$ injection because its population increased 4-fold during the transition phase, but remained between 1 and $1.610^{6}$ copies/mL during next phases. So, $\mathrm{SRB}$ seemed to not be stimulated by $\mathrm{H}_{2}$ addition, despite competition of SRB, acetogens and methanogens can occur during anerobic digestion (Dar et al., 2008). Wahid et al., 2019 showed a decreasing of SRB under high $\mathrm{H}_{2}$ partial pressure suggesting that $\mathrm{H}_{2}$ added was mainly used by hydrogenotrophic methanogen and homo-acetogenic bacteria.

BDT decrease among bacterial community was observed during the experiment. BDT are responsible of hydrolytic and acidogenic activity (Jaenicke et al., 2011). However, the relative decrease of BDT did not affect the COD removal efficiency showing that it did not affect hydrolytic and acidogenic activity. Relative decrease can be explained by the increasing of homoacetogenic bacteria.

These results showed that initial microbial community of an anaerobic digestor was able to catalyze the bio-methanation reaction by first using mainly the homoacetogenicacetoclastic pathway. Then, addition of $\mathrm{H}_{2}$ in the anerobic digestor led to community adaptation to the hydrogenotrophic pathway of $\mathrm{CH}_{4}$ production due to faster growth rate of hydrogenotrophic archaea. However, both pathways seemed to co-exist at each phase. 


\section{Conclusion}

In-situ biogas upgrading up to $97.9 \% \mathrm{CH}_{4}$ content by bio-methanation has been shown feasible at pilot-scale with high biogas productivity up to $1.7 \mathrm{Nm}^{3}{ }_{\text {Biogas }} / \mathrm{m}^{3}$ Bioreactor $/$ day. Moreover, anaerobic digestion performances were not affected by the in-situ biomethanation. Both hydrogenotrophic and homoacetogenic-acetoclastic pathways have been shown to be involved in methane production. However, improvement is needed to reduce energy used for $\mathrm{H}_{2}$ gas-to-liquid transfer in order to be economically feasible which could be done by using a pressurized bioreactor or a submerged membrane for $\mathrm{H}_{2}$ injection.

\section{Supplementary material}

E-supplementary data of this work can be found in online version of the paper.

\section{Availability of data and materials}

The datasets used and/or analyzed during the current study are available from the corresponding author on reasonable request.

\section{Acknowledgements}

This work was supported by the French Environment and Energy Management Agency (ADEME), Cristal-Union, and GRTgaz. Authors also would like to thank ARD (Pomacle, France) for sharing their expertise on anaerobic digestion.

\section{References}


1. Alfaro, N., Fdz-Polanco, M., Fdz-Polanco, F., Díaz, I., 2019. H2 addition through a submerged membrane for in-situ biogas upgrading in the anaerobic digestion of sewage sludge. Bioresour. Technol. 280, 1-8. https://doi.org/10.1016/j.biortech.2019.01.135

2. Braga Nan, L., Trably, E., Santa-Catalina, G., Bernet, N., Delgenès, J.-P., Escudié, R., 2020. Biomethanation processes: new insights on the effect of a high $\mathrm{H} 2$ partial pressure on microbial communities. Biotechnol. Biofuels 13, 141. https://doi.org/10.1186/s13068-020-01776-y

3. Cazier, E.A., Trably, E., Steyer, J.P., Escudie, R., 2015. Biomass hydrolysis inhibition at high hydrogen partial pressure in solid-state anaerobic digestion. Bioresour. Technol. 190, 106-113. https://doi.org/10.1016/j.biortech.2015.04.055

4. Dar, S.A., Kleerebezem, R., Stams, A.J.M., Kuenen, J.G., Muyzer, G., 2008. Competition and coexistence of sulfate-reducing bacteria, acetogens and methanogens in a lab-scale anaerobic bioreactor as affected by changing substrate to sulfate ratio. Appl. Microbiol. Biotechnol. 78, 1045-1055. https://doi.org/10.1007/s00253-008-1391-8

5. Deschamps, L., Merlet, D., Lemaire, J., Imatoukene, N., Filali, R., Clément, T., Lopez, M., Theoleyre, M.-A., 2021. Excellent performance of anaerobic membrane bioreactor in treatment of distillery wastewater at pilot scale. J. Water Process Eng. 41, 102061. https://doi.org/10.1016/j.jwpe.2021.102061

6. Díaz, I., Fdz-Polanco, F., Mutsvene, B., Fdz-Polanco, M., 2020. Effect of operating pressure on direct biomethane production from carbon dioxide and 
exogenous hydrogen in the anaerobic digestion of sewage sludge. Appl. Energy 280, 115915. https://doi.org/10.1016/j.apenergy.2020.115915

7. Díaz, I., Pérez, C., Alfaro, N., Fdz-Polanco, F., 2015. A feasibility study on the bioconversion of $\mathrm{CO} 2$ and $\mathrm{H} 2$ to biomethane by gas sparging through polymeric membranes. Bioresour. Technol. 185, 246-253. https://doi.org/10.1016/j.biortech.2015.02.114

8. Fu, S., Angelidaki, I., Zhang, Y., 2020. In situ Biogas Upgrading by CO2-toCH4 Bioconversion. Trends Biotechnol. S0167779920302286. https://doi.org/10.1016/j.tibtech.2020.08.006

9. Fukuzaki, S., Nishio, N., Shobayashi, M., Nagai, S., 1990. Inhibition of the Fermentation of Propionate to Methane by Hydrogen, Acetate, and Propionate. Appl. Environ. Microbiol. 56, 719.

10. Garrity, G.M., Holt, J.G., Whitman, W.B., Keswani, J., Boone, D.R., Koga, Y., Miller, T.L., Stetter, K.O., Zellner, G., Chong, S.C., Huber, H., Huber, G., Ferry, J.G., Ollivier, B., Mah, R.A., Sowers, K.R., Zhilina, T.N., Baker, C.C., Romesser, J.A., Grant, W.D., Patel, G.B., McGenity, T.J., Kamekura, M., Ventosa, A., Kobayashi, T., Oren, A., Montalvo-Rodríguez, R., Vreeland, R.H., Tindall, B.J., Huber, R., Xu, Y., Zhou, P., Reysenbach, A.-L., Langworthy, T.A., Tian, X., Zillig, W., Kobayashi, T., Hafenbradl, D., 2001. Phylum All. Euryarchaeota phy. nov., in: Boone, D.R., Castenholz, R.W., Garrity, G.M. (Eds.), Bergey’s Manual® of Systematic Bacteriology: Volume One : The Archaea and the Deeply Branching and Phototrophic Bacteria. Springer New York, New York, NY, pp. 211-355. https://doi.org/10.1007/978-0-387-216096_17 
11. Götz, M., Lefebvre, J., Mörs, F., McDaniel Koch, A., Graf, F., Bajohr, S., Reimert, R., Kolb, T., 2016. Renewable Power-to-Gas: A technological and economic review. Renew. Energy 85, 1371-1390. https://doi.org/10.1016/j.renene.2015.07.066

12. Horiuchi, J.-I., Shimizu, T., Tada, K., Kanno, T., Kobayashi, M., 2002. Selective production of organic acids in anaerobic acid reactor by $\mathrm{pH}$ control. Bioresour. Technol. 82, 209-213. https://doi.org/10.1016/S0960-8524(01)00195-X

13. Jaenicke, S., Ander, C., Bekel, T., Bisdorf, R., Dröge, M., Gartemann, K.-H., Jünemann, S., Kaiser, O., Krause, L., Tille, F., Zakrzewski, M., Pühler, A., Schlüter, A., Goesmann, A., 2011. Comparative and Joint Analysis of Two Metagenomic Datasets from a Biogas Fermenter Obtained by 454Pyrosequencing. PLoS ONE 6, e14519. https://doi.org/10.1371/journal.pone.0014519

14. Jensen, M.B., Ottosen, L.D.M., Kofoed, M.V.W., 2021. H2 gas-liquid mass transfer: A key element in biological Power-to-Gas methanation. Renew. Sustain. Energy Rev. 147, 111209. https://doi.org/10.1016/j.rser.2021.111209

15. Lau, R., Peng, W., Velazquez-Vargas, L.G., Yang, G.Q., Fan, L.-S., 2004. Gas-Liquid Mass Transfer in High-Pressure Bubble Columns. Ind. Eng. Chem. Res. 43, 1302-1311. https://doi.org/10.1021/ie030416w

16. Luo, G., Angelidaki, I., 2013a. Hollow fiber membrane based H2 diffusion for efficient in situ biogas upgrading in an anaerobic reactor. Appl. Microbiol. Biotechnol. 97, 3739-3744. https://doi.org/10.1007/s00253-013-4811-3

17. Luo, G., Angelidaki, I., 2013b. Co-digestion of manure and whey for in situ biogas upgrading by the addition of $\mathrm{H} 2$ : process performance and microbial 
insights. Appl. Microbiol. Biotechnol. 97, 1373-1381.

https://doi.org/10.1007/s00253-012-4547-5

18. Moletta, R., 2015. La méthanisation. Éd. Tec \& doc : Lavoisier.

19. Moletta, R., 2005. Winery and distillery wastewater treatment by anaerobic digestion. Water Sci. Technol. 51, 137-144.

https://doi.org/10.2166/wst.2005.0017

20. Muñoz, R., Meier, L., Diaz, I., Jeison, D., 2015. A review on the state-of-the-art of physical/chemical and biological technologies for biogas upgrading. Rev. Environ. Sci. Biotechnol. 14, 727-759. https://doi.org/10.1007/s11157-0159379-1

21. Murphy, J.D., Thanasit Thamsiriroj, 2013. Fundamental science and engineering of the anaerobic digestion process for biogas production, in: The Biogas Handbook. Elsevier, pp. 104-130. https://doi.org/10.1533/9780857097415.1.104

22. Ojeda, F., Bakonyi, P., Buitrón, G., 2017. Improvement of methane content in a hydrogenotrophic anaerobic digester via the proper operation of membrane module integrated into an external-loop. Bioresour. Technol. 245, 1294-1298. https://doi.org/10.1016/j.biortech.2017.08.183

23. Peillex, J.-P., Fardeau, M.-L., Belaich, J.-P., 1990. Growth of Methanobacterium thermoautotrophicum on $\mathrm{H} 2 \square \mathrm{CO} 2$ : High $\mathrm{CH} 4$ productivities in continuous culture. Biomass 21, 315-321. https://doi.org/10.1016/0144-4565(90)90080-4

24. Pratofiorito, G., Hackbarth, M., Mandel, C., Madlanga, S., West, S., Horn, H., Hille-Reichel, A., 2021. A membrane biofilm reactor for hydrogenotrophic methanation. Bioresour. Technol. 321, 124444. https://doi.org/10.1016/j.biortech.2020.124444 
25. Wahid, R., Mulat, D.G., Gaby, J.C., Horn, S.J., 2019. Effects of H2:CO2 ratio and $\mathrm{H} 2$ supply fluctuation on methane content and microbial community composition during in-situ biological biogas upgrading. Biotechnol. Biofuels 12, 104. https://doi.org/10.1186/s13068-019-1443-6

26. Wang, W., Xie, L., Luo, G., Zhou, Q., Angelidaki, I., 2013. Performance and microbial community analysis of the anaerobic reactor with coke oven gas biomethanation and in situ biogas upgrading. Bioresour. Technol. 146, 234-239. https://doi.org/10.1016/j.biortech.2013.07.049

27. Wise, D.L., Cooney, C.L., Augenstein, D.C., 1978. Biomethanation: Anaerobic fermentation of $\mathrm{CO} 2, \mathrm{H} 2$ and $\mathrm{CO}$ to methane. Biotechnol. Bioeng. 20, 11531172. https://doi.org/10.1002/bit.260200804

28. Yasin, M., Jeong, Y., Park, S., Jeong, J., Lee, E.Y., Lovitt, R.W., Kim, B.H., Lee, J., Chang, I.S., 2015. Microbial synthesis gas utilization and ways to resolve kinetic and mass-transfer limitations. Bioresour. Technol. 177, 361-374. https://doi.org/10.1016/j.biortech.2014.11.022 
Table. 1 In-situ bio-methanation performances.

Table 2: Performance comparison of study using membrane bioreactor for bio-methanation process. ${ }^{a}$ Estimated from available data, ${ }^{b}$ Not precised but absence of bubbling through the membrane suggest a yield closed to $100 \%$

Fig. 1: Schematic diagram of the pilot scale anaerobic membrane bioreactor developed for biomethanation.

Fig.2: Process performance evaluation during in-situ bio-methanation. Phase 0: Set-up phase of anaerobic digestion without $\mathrm{H}_{2}$ addition. Phase 1: In-situ bio-methanation with low OLR (2.7 $\mathrm{kg}_{\mathrm{COD}} / \mathrm{m}^{3} /$ day). Phase 2: In-situ bio-methanation with high OLR $\left(3.9 \mathrm{~kg} \mathrm{COD} / \mathrm{m}^{3} / \mathrm{day}\right)$. Phase 3: In-situ bio-methanation with high OLR $\left(4.4 \mathrm{~kg}_{\mathrm{COD}} / \mathrm{m}^{3} /\right.$ day $)$ and high pressure to enhance gasto-liquid transfer. Phase 4: Overload organic matter and $\mathrm{H}_{2}$. Phase 5: Intermittent $\mathrm{H}_{2}$ addition. Fig. 3: Phase 4: Effect of high $\mathrm{H}_{2}$ injection during acidification on biogas production and $\mathrm{pH}$ Fig. 4: Effect of in-situ bio-methanation on microbial community. ARC: archaea, BAC: bacteria, MMB: Methanomicrobiales, MBT: Methanobacteriales, Mst: Methanosaetaceae and BDT: Bacteroidetes. Phase 0: Set-up phase of anaerobic digestion without $\mathrm{H}_{2}$ addition. Phase 1: In-situ bio-methanation with low OLR $\left(2.7 \mathrm{~kg}\right.$ COD $/ \mathrm{m}^{3} /$ day $)$. Phase 2 : In-situ biomethanation with high OLR $\left(3.9 \mathrm{~kg} \mathrm{COD} / \mathrm{m}^{3} /\right.$ day $)$. Phase 3: In-situ bio-methanation with high OLR ( $4.4 \mathrm{~kg} \mathrm{COD}_{\mathrm{C}} / \mathrm{m}^{3} /$ day) and high pressure to enhance gas-to-liquid transfer. Overload: Fast increase of COD concentration substrate and $\mathrm{H}_{2}$ 
Tables

\begin{tabular}{|c|c|c|c|c|c|}
\hline & & Phase 0 & Phase 1 & Phase 2 & Phase 3 \\
\hline \multicolumn{2}{|l|}{ HRT (days) } & $3.4 \pm 0.6$ & $3.3 \pm 0.1$ & $2.8 \pm 0.1$ & $2.4 \pm 0.2$ \\
\hline \multicolumn{2}{|c|}{ OLR $\left(\mathrm{kg}_{\mathrm{COD}} / \mathrm{m}^{3}{ }_{\text {Bioreactor }} /\right.$ day $)$} & $3.5 \pm 0.5$ & $2.7 \pm 0.1$ & $3.9 \pm 0.1$ & $4.4 \pm 0.4$ \\
\hline \multicolumn{2}{|c|}{$\mathrm{H}_{2}$ Flowrate $(\mathrm{NL} / \mathrm{h})$} & 0 & 7.2 & 9 & 11.6 \\
\hline \multirow{3}{*}{ Biogas composition } & $\begin{array}{c}\mathrm{CH}_{4} \\
(\%)\end{array}$ & $74.7 \pm 0.9$ & $97.4 \pm 0.6$ & $82.8 \pm 1.6$ & $97.9 \pm 1.1$ \\
\hline & $\begin{array}{l}\mathrm{CO}_{2} \\
(\%)\end{array}$ & $25.3 \pm 0.9$ & $1.5 \pm 0.8$ & $4.3 \pm 0.9$ & $1.4 \pm 0.5$ \\
\hline & $\mathrm{H}_{2}(\%)$ & & $1.1 \pm 0.5$ & $12.9 \pm 1.0$ & $0.7 \pm 1.3$ \\
\hline \multicolumn{2}{|c|}{ Liquide membrane pressure $\left(\right.$ bar $\left._{\mathrm{g}}\right)$} & 0.3 & 0.4 & 0.4 & 0.6 \\
\hline \multicolumn{2}{|c|}{ COD removal efficiency $(\%)$} & $94.8 \pm 3.0$ & $96.0 \pm 2.0$ & $96.8 \pm 0.4$ & $95.7 \pm 0.2$ \\
\hline \multicolumn{2}{|c|}{ Biogaz flow (NL/h) } & $8.6 \pm 1.1$ & $7.5 \pm 0.2$ & $10.9 \pm 0.3$ & $10.8 \pm 0.3$ \\
\hline \multicolumn{2}{|l|}{$\mathrm{pH}$} & $7.3 \pm 0.1$ & $7.6 \pm 0.1$ & $7.7 \pm 0.1$ & $7.9 \pm 0.2$ \\
\hline \multicolumn{2}{|c|}{$\mathrm{TAC}\left(\mathrm{mg}_{\mathrm{CaCO} 3} / \mathrm{L}\right)$} & $1866 \pm 155$ & $1122 \pm 74$ & $1491 \pm 11$ & $1453 \pm 90$ \\
\hline \multicolumn{2}{|c|}{$\mathrm{H}_{2}$ consumption yield $(\%)$} & - & 98.9 & 89.3 & 99.2 \\
\hline
\end{tabular}




\begin{tabular}{|c|c|c|c|c|c|c|c|c|c|c|}
\hline & $\begin{array}{c}\text { In- } \\
\text { situ/Ex- } \\
\text { situ }\end{array}$ & $\begin{array}{l}\text { Membrane } \\
\text { type }\end{array}$ & $\begin{array}{l}\text { Microbubbles } \\
\text { /Biofilm }\end{array}$ & $\begin{array}{c}\text { Pores } \\
(\mu \mathrm{m})\end{array}$ & Temperature & $\begin{array}{c}\text { Surface/volume } \\
\left(\mathrm{m}^{2} / \mathrm{m}^{3}\right)\end{array}$ & $\begin{array}{c}\mathrm{CH}_{4} \text { production } \\
\text { rate } \\
\mathrm{Nm}^{3} / \mathrm{m}^{3} \text { Bioreactor/day }\end{array}$ & $\begin{array}{c}\mathrm{H}_{2} \text { feed } \\
\text { flowrate } \\
\left(\mathrm{NL} / \mathrm{m}^{2} / \mathrm{h}\right)\end{array}$ & \begin{tabular}{|c|}
$\mathrm{CH}_{4}$ \\
content \\
$(\%)$
\end{tabular} & $\begin{array}{c}\mathrm{H}_{2} \\
\text { consumption } \\
\text { yield }(\%)\end{array}$ \\
\hline $\begin{array}{c}\text { Díaz et al., } \\
2015\end{array}$ & Ex-situ & PVDF & Microbubbles & 0.45 & $55^{\circ} \mathrm{C}$ & 30 & 8.8 & 56 & $80 \%^{\mathrm{a}}$ & $95 \%$ \\
\hline Diaz 2019 & In-situ & Polymeric & Microbubbles & 0.4 & $35^{\circ} \mathrm{C}$ & 4.7 & 0.54 & 7.8 & $73.1 \%$ & $93.9 \%$ \\
\hline $\begin{array}{l}\text { Pratofiorito } \\
\text { et al., } 2021\end{array}$ & Ex-situ & $\begin{array}{l}\text { hydrophobic } \\
\text { tubular }\end{array}$ & Biofilm & 0.2 & $37^{\circ} \mathrm{C}$ & 57.9 & 1.2 & 3.1 & $97 \%$ & $100 \%^{b}$ \\
\hline $\begin{array}{l}\text { Present } \\
\text { study }\end{array}$ & In-situ & $\begin{array}{l}\text { Ceramic } \\
\text { tubular }\end{array}$ & $\begin{array}{l}\text { Diffusion and } \\
\text { microbubbles }\end{array}$ & 0.1 & $37^{\circ} \mathrm{C}$ & 1.7 & 1.7 & 46 & $97.9 \%$ & $99.2 \%$ \\
\hline
\end{tabular}


Figures

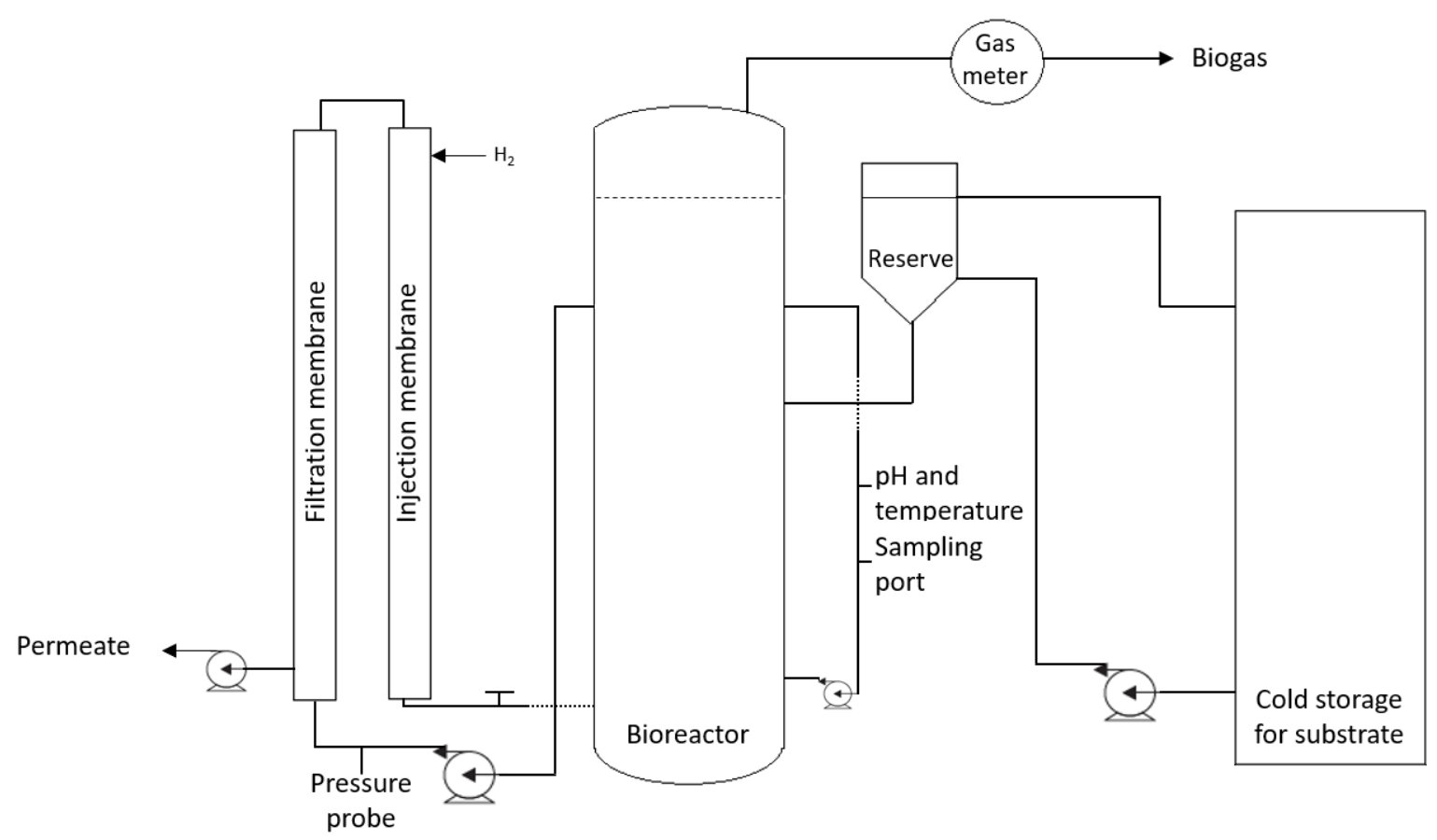



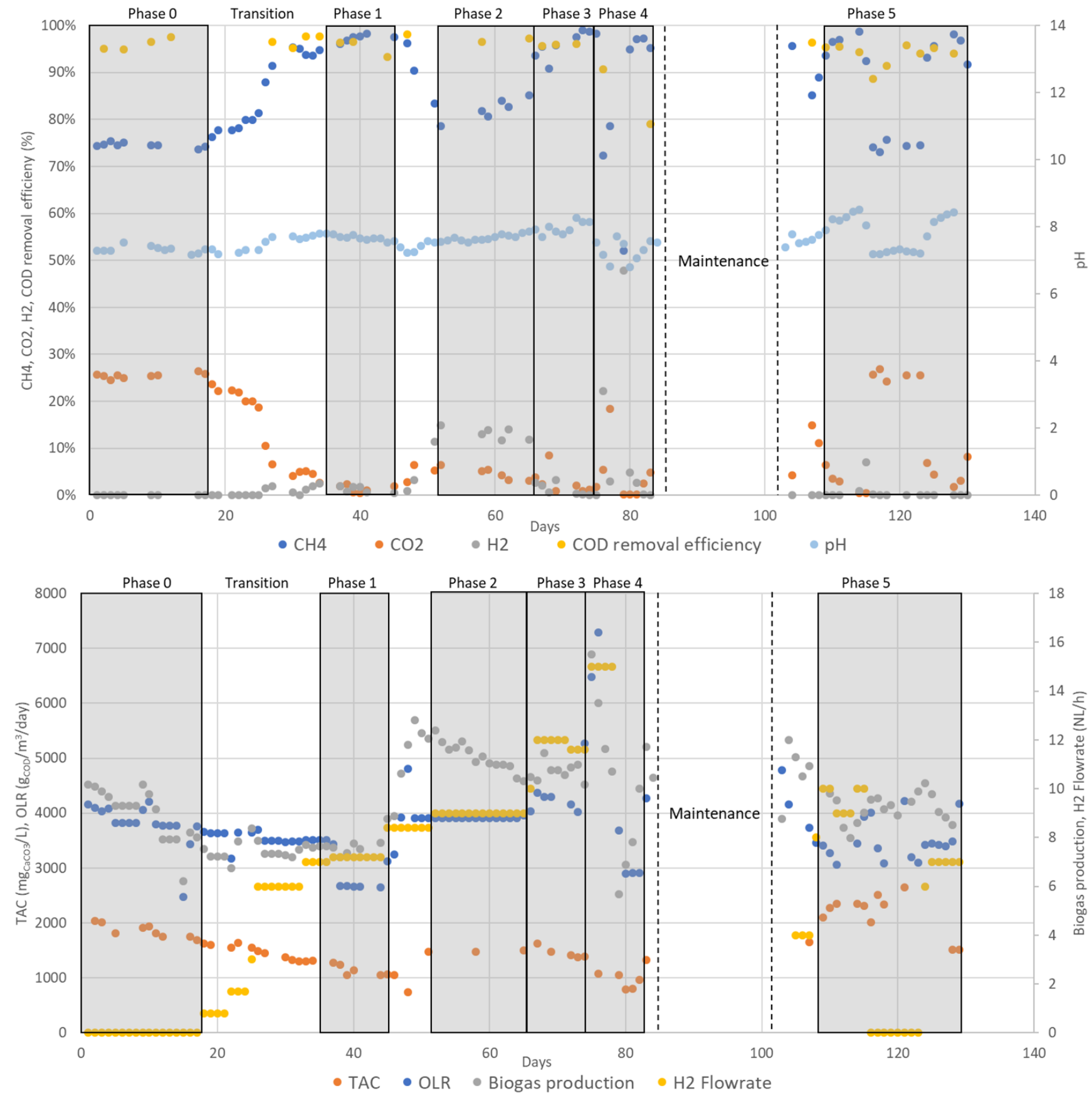


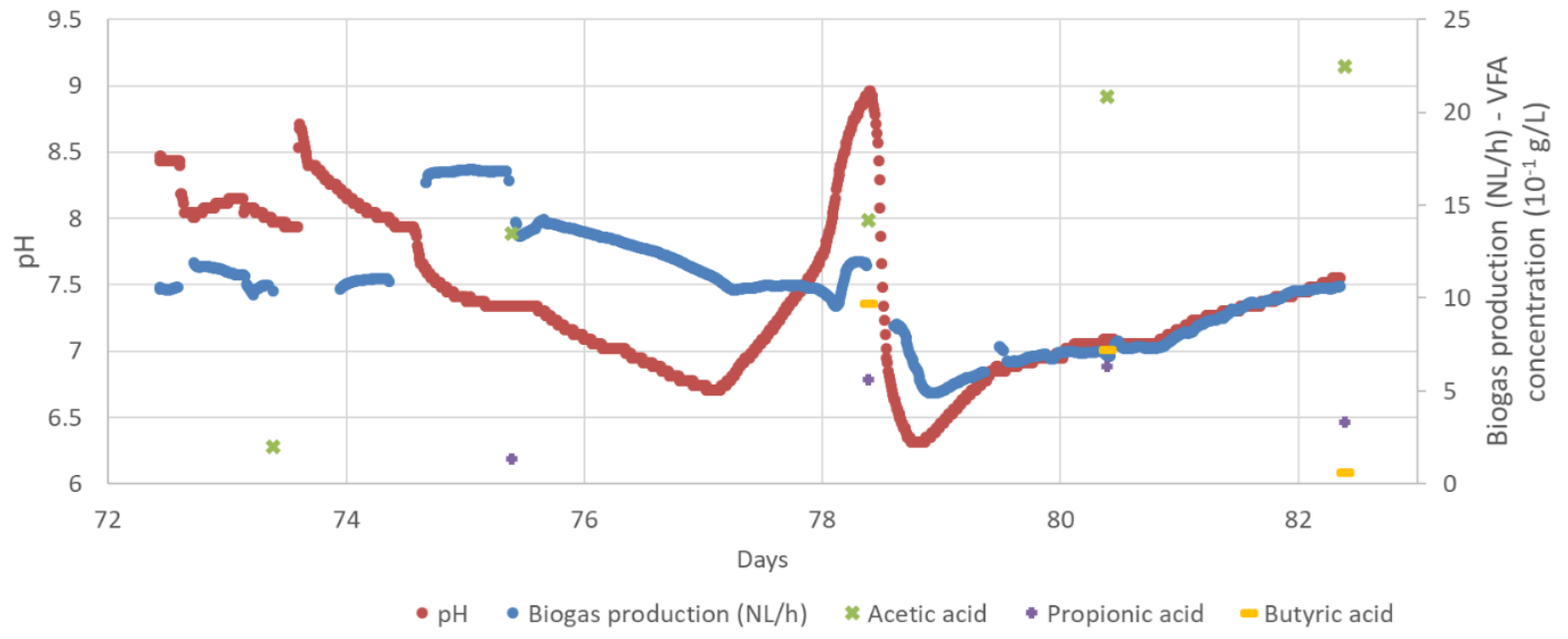




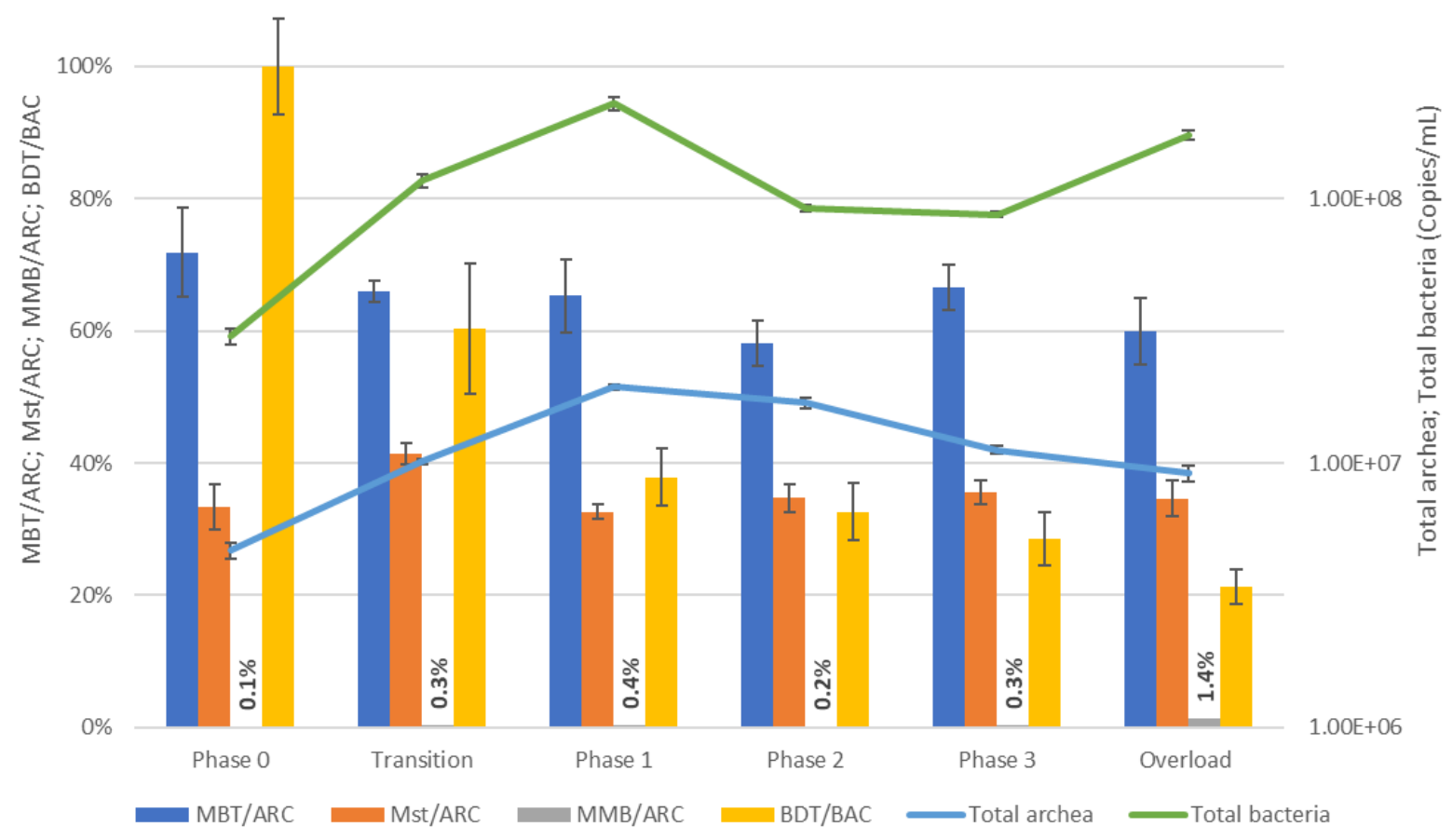

